\title{
Effects of self-service technology on customer value and customer readiness: The case of banking industry
}

\author{
Parviz Khadem $^{\mathrm{a}}$ and Seyed Mahdi Mousavi ${ }^{\mathrm{b}^{*}}$
}

${ }^{a}$ M.A. of Public Management, Islamic Azad University, Arak Branch

${ }^{b}$ Public Management, Islamic Azad University, Arak Branch, Arak, Iran

\section{H R O N I C L E \\ A B S T R A C T}

\section{Article history:}

Received January 12, 2013

Received in revised format

30 April 2013

Accepted 5 June 2013

Available online

June 72013

Keywords:

Continuous internet banking

Cost reduction

Self-control

\begin{abstract}
The recent development on internet banking has contributed to this industry, significantly. People could do their banking transactions by clicking a bottom and transfer funds, pay bills, etc. In this paper, we present an empirical investigation to find out the effects of different factors on continuous internet banking. The proposed study of this paper has adopted a questionnaire, which was originally developed by Ho and Ko (2008) [Ho, S. H., \& Ko, Y. Y. (2008). Effects of self-service technology on customer value and customer readiness: The case of Internet banking. Internet Research, 18(4), 427-446.]. We have used Pearson correlation test as well as stepwise regression techniques to verify the effect of different factors and the results of our survey show that four variables of easy implementation, usefulness, cost reduction and self-control positively influence continuous internet banking.
\end{abstract}

(c) 2013 Growing Science Ltd. All rights reserved.

\section{Introduction}

Service quality plays an important role on the success of business models and there are literally many studies for measuring the relative success of service quality (Cronin Jr \& Taylor, 1992; Parasuraman et al., 1994; Anderson \& Gerbing, 1988; Davies, et al., 1999; Robinson et al., 1999; Zhang et al., 2008). According to Hensmans et al. (2001), the emergence of electronic commerce raises some concerns about the constructing and leveraging of legitimacy for both practitioners and scholars of strategy. The applications of some existing challenges for the financial services industry, as for some other industries, are only starting to become clear. Hensmans et al. (2001) contributed to these initial insights by developing a conceptual model, which considers which e-strategies 'bricks' and 'clicks' adopt to improve their competitiveness. They detected four relevant organizational kinds in the emerging online financial services industry and evaluated tied to legitimacy-providing organizations for their potential both as buffers against environmental turbulence and bridges towards changing stakeholder perspectives.

*Corresponding author.

E-mail addresses: mahdi.moussavi@yahoo.com (S. M. Mousavi) 
Waite et al. (2011) compared consumer expectations of bank website functionality for two online task scenarios including information search and transaction. The study implemented task technology fit theory and followed a novel methodological technique by implementing expectation 'fit' based on a set of website attributes. They reported several points of similarity and difference with regard to consumer expectations of website attributes according to task context and made an important and original contribution to both practice and theory. For marketing practitioners, the findings notified how they could 'manage' expectations to facilitate positive website experiences.

Lin and Hsieh (2006) examined how technology readiness (TR) affects customers' perception and adoption of self-service technologies (SSTs) through development of an empirical framework to explore the relationships among TR, perceived service quality, satisfaction and behavioral intentions toward SSTs. Their results indicated that TR could impact perceived SST service quality and behavioral intentions, while perceived SST service quality had a positive effect on customer satisfaction and behavioral intentions toward SSTs.

Chang and Wildt (1994) investigated Price, non-price product information, and purchase intention, together with the intervening variables of perceived price, perceived quality, and perceived value. They reported that objective price influenced perceived price positively and reference price influenced it, negatively. They supported the positive price-perceived quality relationship found in previous studies and demonstrated that the effect of price on perceived quality was lessened in the presence of substantial direct product information. Finally, the results demonstrated that a trade-off between perceived price and perceived quality could lead to perceived value, and perceived value was a primary factor influencing purchase intention.

Eriksson and Nilsson (200) concentrated on buyers' continued implementation of SST. In comparison with new buyer acquisition, continued implementation was a cost-effective market strategy aimed at retaining buyers. They reported that continued implementation of SST was positively influenced by buyers' perceived usefulness. They also reported that continued implementation of SST was negatively influenced by multichannel satisfaction.

Meuter et al. (2003) explored usage patterns and benefits of using SSTs based on a sample of 823 consumers. They also evaluated the impact of individual characteristics, specifically technology anxiety (TA) and particular demographics, on SST usage patterns and satisfaction levels. They reported that respondents with higher levels of TA implement fewer SSTs and TA was a better, more consistent predictor of SST usage. In their survey, TA influenced overall levels of satisfaction, intentions to use the SST again and the likelihood of participating in positive word-of-mouth for those consumers who had an initially satisfying experience.

Bateson (1985) examined consumers' choice process when they were encountered with the choice between a do-it-yourself option and a more traditional service delivery system. They reported that across a number of services there were individuals who would implement the self-service option even if the usual monetary or convenience incentives were withdrawn. Bitner et al. (2002) discussed how implement SSTs, practically. Bobbitt and Dabholkar (2001) presented integration attitudinal theories to understand and to predict implementation of technology-based self-service and discussed their model for an internet based application.

Chan et al. (1998) discussed some issues related to innovative products in Hong Kong industries. Ho and Ko (2008) investigated the effects of self-service technology on customer value and customer readiness for a case of internet banking. McKechnie et al. (2006) applied a technology acceptance model to the online retailing of financial services and discussed important factors influencing it. Wang et al. (2003) discussed the determinants of user acceptance of internet banking in an empirical investigation. 
Gerrard and Cunningham (2003) discussed the diffusion of internet banking among Singapore consumers. Chen et al. (2002) presented a comprehensive survey on enticing online consumers in terms of technology acceptance perspective. Parasuraman et al. (1985) presented a novel conceptual model of service quality and its implications for future research. Parasuraman $(1990,2000)$ presented Technology Readiness Index (TRI) as a multiple-item scale to measure readiness to embrace new technologies. Weinstein (2002) discussed customer retention using a usage segmentation and customer value approach.

\section{The proposed study}

The proposed model of this paper uses a model originally developed by Ho and Ko (2008) for investigating the effects of self-service technology on customer value and customer readiness in a case study of internet banking. Fig. 1 demonstrates details of our survey.

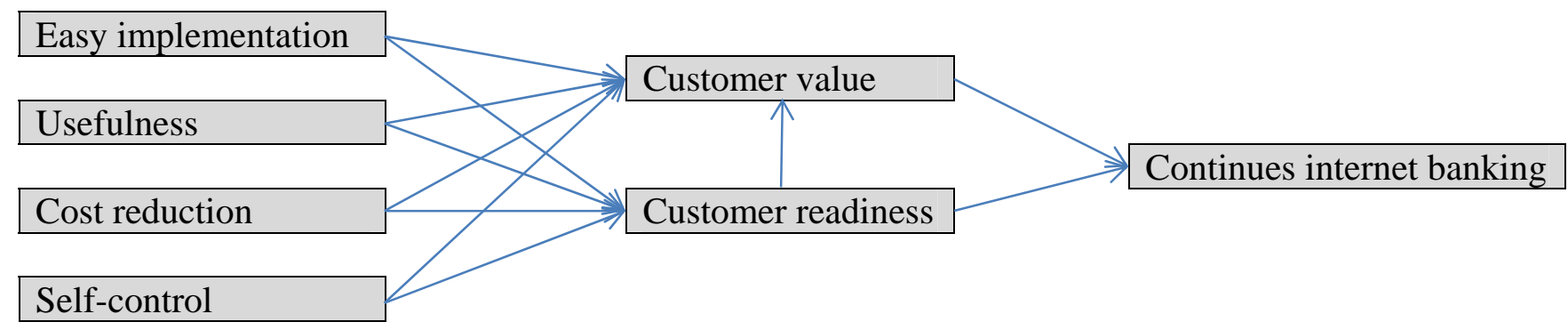

Fig. 1. The proposed study (Ho \& Ko, 2002)

The sample size is selected from all population of customers who use banking services from Bank Mellet, an Iranian bank and it is calculated as follows,

$$
N=Z_{\alpha / 2}^{2} \frac{p \times q}{e^{2}},
$$

where $N$ is the sample size, $p=1-q$ represents the probability, $z_{\alpha / 2}$ is CDF of normal distribution and finally $\varepsilon$ is the error term. For our study we assume $p=0.5, z_{\alpha / 2}=1.96$ and $e=0.99$, the number of sample size is calculated as $N=384$. The questionnaire consists of 34 questions and in order to validate the questionnaire, we have selected a sample of 30 customers and distributed the questionnaire among them. Cronbach alpha was calculated as 0.88 , which was well above the minimum level of 0.70 and it validated the overall questionnaire. Next, we have distribted the questionnaire among 400 customers and analyzed the results. The results of the study are analyzed based on Pearson correlation ratios as well as stepwise regression analysis.

\section{The results}

In order to examine different components of our survey, we first present the results of Pearson correlation ratios, which are summarized in Fig. 2 as follows,

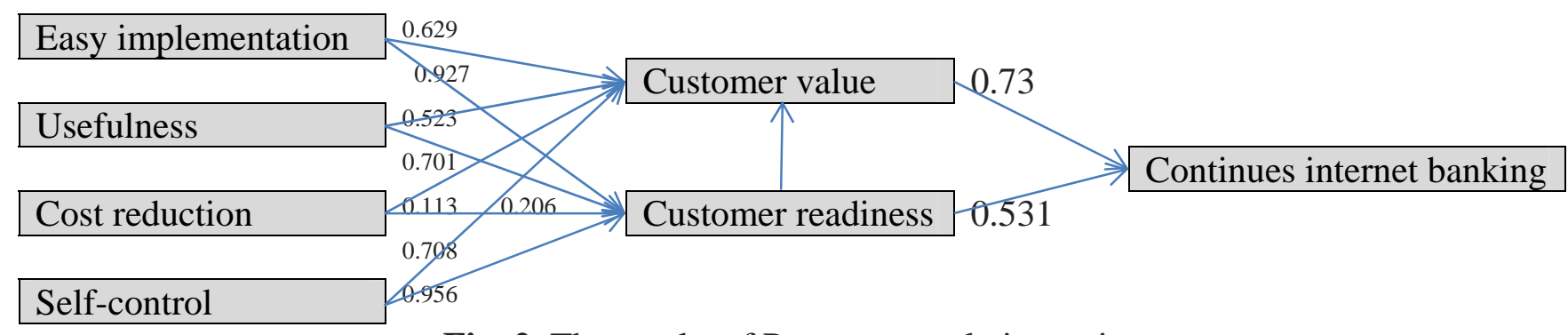

Fig. 2. The results of Pearson correlation ratios 
As we can observe from the results of Fig. 2, there are some positive and meaningful relationships between different components of the proposed study. Next, we present some statistical observations on linear regression analysis. Table 1 demonstrates the results of our survey.

Table 1

The summary of statistical observations

\begin{tabular}{|c|c|c|c|c|c|c|c|c|c|c|}
\hline \multirow{2}{*}{ Model } & \multirow{2}{*}{$\mathrm{R}$} & \multirow{2}{*}{$R^{2}$} & \multirow{2}{*}{$\bar{R}^{2}$} & \multirow{2}{*}{$\begin{array}{c}\text { Std. } \\
\text { Error }\end{array}$} & \multicolumn{5}{|c|}{ Change Statistics } & \multirow{2}{*}{$\begin{array}{l}\text { Durbin- } \\
\text { Watson }\end{array}$} \\
\hline & & & & & $R^{2}$ & $\mathrm{~F}$ & df1 & $\mathrm{df} 2$ & Sig. & \\
\hline 1 & $.981^{\mathrm{a}}$ & .962 & .962 & .08552 & .962 & 3614.909 & 4 & 383 & .000 & 1.970 \\
\hline
\end{tabular}

The results of Table 1 indicate that there are some positive and meaningful relationship between continuous internet banking as dependent variable and other independent variables. Table 2 summarizes the results of stepwise regression analysis.

\section{Table 2}

The summary of regression analysis

\begin{tabular}{|c|c|c|c|c|c|c|}
\hline \multirow{2}{*}{ Model } & \multirow{2}{*}{ Independent variables } & \multicolumn{2}{|c|}{ Non-standard coefficients } & \multirow{2}{*}{$\begin{array}{c}\text { Standard coefficients } \\
\text { Beta }\end{array}$} & \multirow{2}{*}{$\mathrm{t}$} & \multirow{2}{*}{ Sig } \\
\hline & & $\mathrm{B}$ & Std. Error & & & \\
\hline \multirow{5}{*}{1} & Intercept & 3.013 & 0.063 & & 3.202 & 0 \\
\hline & Easy implementation & 13.305 & 0.023 & 0.3 & 13.025 & 0 \\
\hline & Usefulness & 21.002 & 0.023 & 0.2 & 3.098 & 0 \\
\hline & Cost reduction & 14.002 & 0.014 & 0.41 & 3.153 & 0 \\
\hline & Self-control & 36.698 & 0.022 & 0.7 & 3.205 & 0 \\
\hline
\end{tabular}

The results of Table 2 clearly specify that four independent variables of easy implementation, usefulness, cost reduction and self-control positively influence continuous internet banking, positively. All t-student values are statistically meaningful when the level of significance is one percent. Therefore, we can confirm that the proposed model presented by Ho and Ko (2008) can be used for the proposed case study of this paper.

\section{Conclusion}

In this paper, we have presented and empirical investigation to study the impact of different factors on continuous internet banking. The proposed study of this paper has adopted a questionnaire, which was originally developed by Ho and Ko (2008). We have used Pearson correlation test as well as stepwise regression techniques to verify the effect of different factors and the results of our survey show that four variables of easy implementation, usefulness, cost reduction and self-control positively influence continuous internet banking. The results of this survey are consistent with the results of Ho and Ko (2008).

As future study, we recommend interested researchers to build a conceptual framework to compare the results of our findings with traditional SERVQUAL model proposed by Parasuraman (1990, 1994, 2000).

\section{Acknowledgment}

The authors would like to thank Bank Mellet for providing support for the accomplishment of this survey. We are also grateful for constructive comments on earlier version of this paper, which have substantially contributed to the quality of this paper. 


\section{References}

Anderson, J. C., \& Gerbing, D. W. (1988). Structural equation modeling in practice: A review and recommended two-step approach. Psychological bulletin, 103(3), 411-423.

Bagozzi, R. P., \& Yi, Y. (1988). On the evaluation of structural equation models. Journal of the academy of marketing science, 16(1), 74-94.

Bateson, J. E. (1985). Self-service consumer: An exploratory study. Journal of retailing, 61(3), 4976.

Bitner, M. J., Ostrom, A. L., \& Meuter, M. L. (2002). Implementing successful self-service technologies. The Academy of Management Executive, 16(4), 96-108.

Bobbitt, L. M., \& Dabholkar, P. A. (2001). Integrating attitudinal theories to understand and predict use of technology-based self-service: the internet as an illustration. International Journal of Service Industry Management, 12(5), 423-450.

Chan, A., Go, F. M., \& Pine, R. (1998). Service innovation in Hong Kong: attitudes and practice. Service Industries Journal, 18(2), 112-124.

Chang, T. Z., \& Wildt, A. R. (1994). Price, product information, and purchase intention: An empirical study. Journal of the Academy of Marketing Science, 22(1), 16-27.

Chen, L. D., Gillenson, M. L., \& Sherrell, D. L. (2002). Enticing online consumers: an extended technology acceptance perspective. Information \& Management, 39(8), 705-719.

Cronin Jr, J. J., \& Taylor, S. A. (1992). Measuring service quality: a reexamination and extension. The journal of marketing, 55-68.

Davies, B., Baron, S., Gear, T., \& Read, M. (1999). Measuring and managing service quality. Marketing Intelligence \& Planning, 17(1), 33-40.

Eriksson, K., \& Nilsson, D. (2007). Determinants of the continued use of self-service technology: The case of Internet banking. Technovation, 27(4), 159-167.

Gerrard, P., \& Cunningham, J. B. (2003). The diffusion of internet banking among Singapore consumers. International Journal of Bank Marketing, 21(1), 16-28.

Hensmans, M., Van den Bosch, F. A., \& Volberda, H. W. (2001). Clicks vs. bricks in the emerging online financial services industry. Long Range Planning, 34(2), 231-247.

Ho, S. H., \& Ko, Y. Y. (2008). Effects of self-service technology on customer value and customer readiness: The case of Internet banking. Internet research,18(4), 427-446.

Lin, J. S. C., \& Hsieh, P. L. (2006). The role of technology readiness in customers' perception and adoption of self-service technologies. International Journal of Service Industry Management, 17(5), 497-517.

McKechnie, S., Winklhofer, H., \& Ennew, C. (2006). Applying the technology acceptance model to the online retailing of financial services. International Journal of Retail \& Distribution Management, 34(4/5), 388-410.

Meuter, M. L., Ostrom, A. L., Bitner, M. J., \& Roundtree, R. (2003). The influence of technology anxiety on consumer use and experiences with self-service technologies. Journal of Business Research, 56(11), 899-906.

Parasuraman, A. (1990). Delivering quality service: Balancing customer perceptions and expectations. New York: Free Press; London: Collier Macmillan.

Parasuraman, A., Zeithaml, V. A., \& Berry, L. L. (1994). Reassessment of Expectations as a Comparison Standard in Measuring Service Quaiity: implications for Furtiier Research. Journal of marketing, 58, 111-24.

Parasuraman, A. (2000). Technology Readiness Index (TRI) a multiple-item scale to measure readiness to embrace new technologies. Journal of Service Research, 2(4), 307-320.

Robinson, S. (1999). Measuring service quality: current thinking and future requirements. Marketing Intelligence \& Planning, 17(1), 21-32.

Waite, K., Harrison, T., \& Hunter, G. (2011). Exploring bank website expectations across two task scenarios. Journal of Financial Services Marketing, 16(1), 76-85. 
Wang, Y. S., Wang, Y. M., Lin, H. H., \& Tang, T. I. (2003). Determinants of user acceptance of internet banking: an empirical study. International Journal of Service Industry Management, 14(5), 501-519.

Weinstein, A. (2002). Customer retention: a usage segmentation and customer value approach. Journal of Targeting, Measurement and Analysis for Marketing,10(3), 259-268.

Zhang, N., Guo, X., \& Chen, G. (2008). IDT-TAM integrated model for IT adoption. Tsinghua Science \& Technology, 13(3), 306-311. 